\title{
Legalitas Lembaga Bantuan Hukum terhadap Anak Korban Tindak Pidana Menurut Sistem Peradilan Pidana Anak di Wilayah Hukum Bima
}

\author{
Suherman \\ STKIP Taman Siswa Bima \\ suherman.mh.mdjafar@gmail.com
}

Artikel Info

Tanggal Publikasi

2020-12-20

Kata Kunci

Lembaga Bantuan

Hukum

Anak Korban Tindak

Pidana

Sistem Peradilan

Pidana Anak

Wilayah Hukum Bima

\section{Abstrak}

Penelitin ini bertujuan untuk mengetahui bagaimana Upaya Pemberian Bantuan Hukum Terhadap Anak Korban Tindak Pidana Menurut Sistem Peradilan Pidana Anak Di Wilayah Hukum Pengadilan Bima. Serta mengindetifikasi permasalahan berupa Bagaimanakah kebijakan formulasi penanggulangan anak sebagai korban tindak pidana dalam sistem peradilan pidana di Indonesia? Bagaimanakah perlindungan hukum terhadap anak di dalam sistem peradilan pidana yang bersifat Restorative Justice? Penelitian ini menggunakan metode pendekatan yuridis normatif, mengkaji data sekunder yang dikumpulkan dengan cara studi pustaka dengan menggunakan pendekatan perundang-undangan (statute approach) dan pendekatan konseptual (conceptual approach).Kebijakan formulasi penanggulangan anak sebagai korban tindak pidana dalam sistem peradilan pidana di Indonesia harus di dilakukan dengan menggunakan pendekatan restorative juctice, yaitu proses penyelesaian yang dilakukan di luar sistem peradilan pidana (criminal justice system) dengan melibatkan korban, pelaku, keluarga korban dan pelaku, masyarakat serta pihak-pihak yang berkepentingan dengan suatu tindak pidana yang terjadi untuk mencapai kesepakatan dan penyelesaian. Kebijakan ini berangkat dari asumsi bahwa tanggapan atau reaksi terhadap pelaku delinkuensi anak tidak akan efektif tanpa adanya kerjasama dan keterlibatan dari korban, pelaku dan masyarakat. Perlindungan hukum terhadap anak sebagai korban di dalam sistem peradilan pidana yang bersifat restorative justice dalam menangani persoalan-persoalan perkara anak yang berkonflik dengan hukum, maka perlu memperhatikan beberapa hal sebagai berikut: Di Pengadilan Negeri, hakim anak wajib melakukan diversi sebelum melakukan pemeriksaan terhadap perkara tindak pidana anak, karena diversi adalah perintah dari UU-SPPA. Dalam proses diversi, hakim anak diberi kesempatan selama 7 (tujuh) hari, wajib melibatkan pihak-pihak terkait dalam suatu musyawarah sesuai syarat dan ketentuan UU-SPPA di pengadilan negeri secara tertutup untuk umum di ruang khusus, dengan memperhatikan asas-asas penyelesaian perkara pidana anak.

\section{PENDAHULUAN}

Fakta-fakta sosial yang belakangan imi sering terjadi dalam kehidupan bermasyarakat adalah permasalahan yang terkait dengan anak, dimana dalam kehidupan sosial yang sangat dipengaruhi oleh berbagai faktor tersebut kita dihadapkan pada permasalahan penanganan anak yang diduga melakukan tidak pidana.

Anak adalah merupakan tumpuan harapan masa depan bangsa, Negara, masyarakat, ataupun keluaraga. Oleh karena kondisinya sebagai anaka, maka diperlukan perlakuan khusus adar dapat tumbuh dan berkembang secara wajar, baik fisik maupun mental dan rohaninya. Bertolak dari hal tersebut, pada hakekatnya pengaturan mengenai anak telah diatur secara tegas tegas dalam konstitusi Indonesia, yaitu berkaitan dengan pengaturan Hak Asasi Manusia dalam Pasal 28B Angka 2 Undangundang Dasar 1945 yang mengatur mengenai hak tumbuh kembang anak serta mendapatkan perlindungan.

Anak merupakan subjek hukum dan aset bangsa yang harus tumbuh dan berkembang menjadi generasi yang berpotensi, berperan dan turut menikmati pembangunan nasional, menuju tercapainya tujuan negara Republik Indonesia sebagaimana diamanatkan dalam alinea ke IV Pembukaan UndangUndang Dasar negara Republik Indonesia Tahun 1945. Oleh sebab itu negara berkewajiban untuk memberikan perlindungan terhadap anak, yang dalam tumbuh kembangnya masih dalam taraf mencari 
bentuk jati dirinya, terlebih lagi ketika mereka berhadapan atau mengalami konflik dengan hukum. Serta dalam rangka ketertiban sosial diperlukan sistem peradilan pidana anak yang mampu memberikan perlindungan dan rasa keadilan terhadap anak sehingga mereka masih memiliki harapan untuk menatap masa depan mereka, tanpa harus terhambat dengan penderitaan trauma masa lalunya yang pernah mengalami tindakan hukum berlebihan di peradilan.

Secara filosofi anak sebagai bagian dari generasi muda, sebagai salah satu sumber daya manusia yang merupakan potensi dan penerus cita-cita perjuangan bangsa di masa yang akan datang, yang memiliki peran strategis serta mempunyai ciri dan sifat khusus, memerlukan pembinaan dan perlindungan yang khusus pula”.

Dalam penjelasan umum Undang-Undang Republik Indonesia Nomor 11 Tahun 2012 Tentang Sistem Peradilan Anak (UU SPPA) disebutkan:

Anak adalah bagian yang tidak terpisahkan dari keberlangsungan hidup manusia dan keberlangsungan sebuah bangsa dan negara. Dalam konstitusi Indonesia, anak memiliki peran strategis yang secara tegas dinyatakan bahwa negara menjamin hak setiap anak atas kelangsungan hidup, tumbuh, dan berkembang serta atas perlindungan dari kekerasan dan diskriminasi. Oleh sebab itu, kepentingan terbaik bagi anak patutdihayati sebagai kepentingan terbaik bagi kelangsungan hidup umat manusia. Konsekuensi dari ketentuan Pasal 28B Undang-Undang Dasar Negara Republik Indonesia Tahun 1945 perlu ditindaklanjuti dengan membuat kebijakan pemerintah yang bertujuan melindungi anak.

Anak perlu mendapat perlindungan dari dampak negatif perkembangan pembangunan yang cepat, arus globalisasi di bidang komunikasi dan informasi, kemajuan ilmu pengetahuan dan teknologi, serta perubahan gaya dan cara hidup sebagian orang tua yang telah membawa perubahan sosial yang mendasar dalam kehidupan masyarakat yang sangat berpengaruh terhadap nilai dan perilaku anak. Penyimpangan tingkah laku atau perbuatan melanggar hukum yang dilakukan oleh Anak, antara lain, disebabkan oleh faktor di luar diri Anak tersebut. Data Anak yang berhadapan dengan hukum dari Direktorat Jenderal Pemasyarakatan menunjukkan bahwa tingkat kriminalitas serta pengaruh negatif penyalahgunaan narkotika, psikotropika, dan zat adiktif semakin meningkat.

Mengingat ciri dan sifat yang khas pada anak dan demi perlindungan terhadap anak, perkara anak yang berhadapan dengan hukum wajib disidangkan di pengadilan pidana anak yang berada di lingkungan peradilan umum. Proses peradilan perkara anak sejak ditangkap, ditahan, dan diadili, pembinaannya wajib dilakukan oleh pejabat khusus yang memahami masalah anak. Namun, sebelum masuk proses peradilan, para penegak hukum, keluarga, dan masyarakat wajib mengupayakan proses penyelesaian di luar jalur pengadilan, yakni melalui pendekatan Restoratif Justice.

Ruang lingkup sistem peradilan pidana anak mencakup banyak ragam dan kompleksitas isu mulai dari anak melakukan kontak pertama dengan polisi, proses peradilan, kondisi tahanan, dan reintegrasi sosial, termasuk pelaku-pelaku dalam proses tersebut. Dengan demikian, istilah sistem peradilan pidana anak merujuk pada legislasi, norma dan standar, prosedur, mekanisme dan ketentuan, institusi dan badan yang secara khusus diterapkan terhadap anak yang melakukan tindak pidana.

Mengacu pada proses ini, maka terdapat 3 (tiga) tahap peradilan anak, tahap pertama, mencakup pencegahan anak dari tindak pidana. Tahap ini meliputi implementasi tujuan kebijakan sosial yang memungkinkan anak dalam pertumbuhannya sesuai dengan kepentingan terbaiknya. Tahap kedua, ditandai anak bersentuhan dengan prosedur formal sistem peradilan pidana. Tahap ini merupakan bentuk tanggung jawab anak melalui proses peradilan pidana. Tahap ketiga, resosialisasi diawali dari proses isolasi di lembaga pemasyarakatan sampai pembebasan anak. 
Tingkat kerentanan dan risiko mengalami kekerasan semakin tinggi dialami oleh anak perempuan, khususnya tindakan pelecehan seksual dan penyalahgunaan kewenangan selama penahanan dan investigasi. Dampak lebih jauh, mereka berpotensi terpapar HIV/AIDS dan penyakit menular lainnya. Kemudian, isu yang terkait dengan tahanan atau narapidana perempuan, khususnya anak perempuan, berkisar pada keselamatan dan kenyamanan, yang mencakup isu kelembagaan, seperti penempatan ruang, fasilitas, dan pelayanan kesehatan reproduksi. Bahkan perempuan termasuk anak perempuan yang dicabut kebebasannya karena berjenis kelamin perempuan, berpotensi mengalami penganiayaan berbasis gender (gender spesific torture). Terkait dengan permasalahan di atas, Aturan Standar Minimum Perserikatan Bangsa-Bangsa (PBB) bagi Tahanan (UN Standard Minimum Rules for the Treatment of Prisoners) Paragraf 8 menegaskan bahwa: Perbedaan kategorisasi tahanan harus dijaga melalui pemisahan institusi atau bagian dari institusi penahanan berdasarkan jenis kelamin, usia, catatan tindak pidana yang dilakukannya, alasan hukum penahanan atau perlakuan terhadap mereka.

Kasus kekerasan dalam rumah tangga (KDRT) yang mengalami peningkatan di wilayah Nusa Tenggara Barat (NTB) memicu peningkatan angka putus sekolah dan perceraian. Kepala Badan Pemberdayaan Perempuan (PP) dan Keluarga Berencana (KB) Provinsi NTB, Hj Ratningdiah, mengemukakan hal itu di Mataram, Minggu (18/10), ketika mengomentari perkembangan KDRT di wilayah NTB. "Ada peningkatan KDRT dan hal itu berakibat peningkatan angka drop out (benhenti) dari sekolah dan kasus perceraian yang juga mengalami peningkatan," ujarnya. Data versi Badan PP dan KB NTB, jumlah kasus KDRT yang menimpa perempuan dan anak pada tahun 2008 tercatat lebih dari 2.000 kasus dan pada tahun 2009 sejak Januari hingga Agustus tercatat sebanyak 919 kasus. Diperkirakan jumlah kasus KDRT di wilayah NTB sampai penghujung tahun 2009 dapat menyamai catatan tahun 2008 atau lebih karena kasus KDRT di bulan September dan Oktober 2009 cukup banyak. "Itu data yang tercatat, kalau yang tidak tercatat bisa lebih banyak lagi sehingga banyak anak yang putus sekolah. Rata-rata lama sekolah anak-anak NTB masih sangat rendah, yakni 6,7 tahun," ujar Ratningdiah. Sementara data perceraian versi Badan PP dan KB NTB, menyebutkan, pada tahun 2007 kasus perceraian mencapai 1.776 perkara yang mengalami peningkatan menjadi 2.000 kasus lebih di tahun 2008. Terbanyak di Kota dan Kabupaten Bima yang mencapai 31,54 persen karena korban KDRT di dua daerah itu berani dan mau mengungkapkan serta melaporkan kasus yang menimpanya kepada pihak berwajib. "Berbeda dengan korban KDRT di Pulau Lombok yang pada umumnya enggan melaporkan peristiwa yang menimpanya sehingga tidak tertangani secara terarah. Bahkan, aksi diam itu memicu poligami," ujarnya. Ratningdiah mencontohkan rendahnya kasus perceraian di Kabupaten Lombok Barat, yakni hanya 4,89 persen, karena korban KDRT lebih memilih mempertahankan keutuhan rumah tangganya meskipun selalu dalam penderitaan. Menurut dia, untuk mencegah terjadinya kasus KDRT yang rentan berakibat putus sekolah dan perceraian itu, Gubernur NTB, KH M Zainul Majdi, berupaya menjalin kerjasama dengan pondok pesantren. Gubernur NTB dan sejumlah pondok pesantren telah menandatangani nota kesepahaman $(\mathrm{MoU})$ untuk memberantas kasus KDRT itu. "Sebagai instansi teknis kami pun terus berupaya menyosialisasikan berbagai regulasi yang berlaku dengan harapan dapat mencegah kasus KDRT yang rentan berakibat putus sekolah dan perceraian itu," ujarnya. Kini, Pemprov NTB telah memiliki Peraturan Daerah (Perda) tentang pencegahan KDRT, yakni Perda Nomor 2 Tahun 2009 tentang Penyelenggaraan Pencegahan dan Perlindungan Perempuan dan Anak Korban Tindak Kekerasan. Perda itu pun telah diperkuat dengan Peraturan Gubernur (Pergub) Nomor 28 Tahun 2009 tentang Mekanisme Penyelenggaraan, Pencegahan, Penanganan dan Standar Operasional Prosedur (SOP) Pelayanan Pada Pusat Pelayanan Terpadu dan Pendampingan Perempuan dan Anak Korban Tindak Kekerasan di NTB. Berdasarkan uraian di atas, Penulis tertarik untuk melakukan sebuah penelitian yang berjudul "Upaya Pemberian Bantuan Hukum Terhadap Anak Korban Tindak Pidana Menurut Sistem Peradilan Pidana Anak Di Wilayah Hukum Pengadilan Bima”. 


\section{METODE PENELITIAN}

Dalam penelitian ini penulis menggunakan metode penelitian sebagai berikut:

\section{Spesifikasi Penelitian}

Tipe penelitian hukum dalam penelitian ini adalah deskriptif analitis dengan pertimbangan bahwa titik tolak penelitian bukan hanya terbatas pada analisis terhadap peraturan perundangundangan yang terkait dengan upaya perlindungan hukum bagi anak sebagai korban dalam sistem peradilan pidana, akan tetapi juga tinjauan terhadap kasus-kasus yang sampai saat ini belum terselesaikan saat ini karena terkendala perangkat perundang-undangan yang belum mengatur dan juga masih bersifat multi interpretasi. Namun demikian, penelitian tidak saja terhadap bahan perundangundangan di Indonesia tetapi juga bahan-bahan dan aturan perundang-undangan dari berbagai negara yang mengatur tentang penanganan upaya penanggulangan anak sebagai korban kejahatan.

Penelitian tahap sinkronisasi vertical (aturan hukum yang tidak bertentangan) dan tahap sinkronisasi horizontal (aturan hukum yangsederajat atau mengatur bidang yang sama), dimana dalam penelitian ini terdapatnya norma yang kabur (multitafsir) dalam proses penanganan anak yang bermasalah dengan hukum, serta belum jelas diatur mengenai syarat aparat penegak hukum yang berwenang dealam menagani kejahatan anak, seperti Kepolisian (Penyidik) dalam Pasal 41 UU No 3 Tahun 1997, Kejaksaan (Penuntut Umum) dalam Pasal 53 UU No 3 Tahun 1997, Hakim dalam Pasal 10 UU No 3 Tahun 1997 tentang syarat yang dianggap berpengalaman dalam menangani kejahatan yang dilakukan oleh Anak sehingga dalam hal ini sejauh mana ukuran yang dipakai sebagai syarat pengalaman untuk menangani tentang kejahatan yang dilakukan oleh anak, apakah ukuran waktu ataupun kuantitas kasus yang pernah ditangani oleh aparat penegak hukum tersebut.

Aspek epistemologi mutlak diperlukan guna menjamin kebenaran dan pertanggungjawaban ilmiah dalam penelitian ini dengan cara mendapatkan pengetahuan dari masalah yang diteliti. Aspek ini relevan dengan metode penelitian yang dipakai untuk mengkaji pokok permasalahan yang ada di dalam penelitian ini. Johny Ibrahim menyatakan bahwa salah satu cara kerja keilmuan adalah ditandai dengan metode. Menetapkan metode penelitian hukum hendaklah beranjak dari hakikat keilmuan hukum. Ilmu hukum memiliki karakteristik ilmu hukum sebagai sui generis yang memiliki arti ilmu hukum merupakan ilmu jenis sendiri, karena ilmu hukum dengan kualitas ilmiah sulit untuk dikelompokkan dalam salah satu cabang pohon ilmu.

\section{Metode Pendekatan}

Untuk menjawab permasalahan penelitian di atas dibutuhkan suatu metode yang tepat. Mencermati permasalahan penelitian maka metode pada penelitian ini menggunakan penelitian yuridis normatif. Penggunaan metode ini didasarkan pada pertimbangan bahwa titik tolak penelitian bukan hanya terbatas pada analisis terhadap peraturan perundang-undangan yang terkait dengan upaya perlindungan hukum bagi anak sebagai korban kejahatan dalam sistem peradilan pidana, akan tetapi juga tinjauan terhadap kasus-kasus yang belum terselesaikan saat ini karena terkendala perangkat perundang-undangan yang belum mengatur dan juga masih bersifat multi interpretasi. Namun demikian, penelitian ini tidak hanya dilakukan terhadap bahan perundang-undangan di Indonesia tetapi juga bahan-bahan dan aturan perundang-undangan dari berbagai negara yang mengatur tentang penanganan upaya penanggulangan anak sebagai korban kejahatan. Dalam penelitian ini ditunjang pendekatan, konseptual, dan pendekatan perundang-undangan.

\section{Teknik Pengumpulan Data}

Upaya pengumpulan data dalam penulisan ini, penulis menggunakan dokumentasi, yaitu dengan melakukan pencarian data dari sumbernya berupa dokumen, fakta dan catatan. Data yang diperlukan dalam penulisan dikumpulkan dengan cara studi dokumen atau studi kepustakaan, yang dilakukan 
untuk mengumpulkan dan menginventarisasi semua data kepustakaan atau data sekunder yang terkait dengan topik penelitian.

Penelitian melakukan pengumpulan data dengan penelitian kepustakaan guna mendapatkan landasan teoritis berupa pendapat-pendapat atau tulisan-tulisan para ahli atau pihak-pihak lain yang berwenang dan juga untuk memperoleh informasi, baik dalam bentuk-bentuk ketentuan formal maupun data melalui naskah resmi yang ada.

\section{Prosedur Pengumpulan Data}

Untuk memperoleh data, penulis melakukan penelitian kepustakaan (library research). Dalam penelitian ini penulis meneliti dan mengumpulkan bahan hukum sebagai alat untuk mengkaji masalah hukum yang terkait dengan perlindungan hukum terhadap anak korban dari kejahatan menurut sistem peradilan pidana anak yang berlaku di Indonesia, meliputi data sekunder bahan hukum primer, data sekuder bahan hukum sekunder, dan data sekunder bahan hukum tersier.

\section{HASIL DAN PEMBAHASAN}

\section{Kebijakan Penanggulangan Anak Sebagai Korban Tindak Pidana Dalam Sistem Peradilan Pidana}

Problematika tindak pidana yang dilakukan oleh anak kini semakin meningkat di masyarakat, baik di negara maju maupun negara sedang berkembang. Perkembangan masyarakat yang berawal dari kehidupan agraris menuju kehidupan industrial telah membawa dampak signifikan terhadap kehidupan tata nilai sosiokultural pada sebagian besar masyarakat. Nilai-nilai yang bersumber dari kehidupan industrial semakin menggeser nilai-nilai kehidupan agraris dan proses tersebut terjadi secara berkesinambungan sehingga pada akhirnya membawa perubahan dalam tata nilai termasuk pola-pola perilaku dan hubungan masyarakat.

Perkembangan seperti ini juga sedang berlangsung di Indonesia dengan menyatunya tata nilai yang bercirikan masyarakat industrial, maka perbenturan antara nilai-nilai lokal tradisional dengan nilai-nilai modernisme tidak dapat terhindarkan. Pada akhirnya, dampak yang paling terasa sebagai akibat dari perubahan sosial yang sangat cepat menuju kehidupan industrial adalah penyimpangan perilaku anak-anak atau remaja.

Kenakalan anak setiap tahun selalu meningkat, apabila dicermati perkembangan tindak pidana yang dilakukan anak selama ini, baik dari kualitas maupun modus operandi yang dilakukan, kadangkadang tindakan pelanggaran yang dilakukan anak dirasakan telah meresahkan semua pihak khususnya para orang tua. Fenomena meningkatnya perilaku tindak kekerasan yang dilakukan anak seolah-olah tidak berbanding lurus dengan usia pelaku. Oleh karena itu, berbagai upaya pencegahan dan penanggulangan kenakalan anak, perlu segera dilakukan.

\section{Penetapan Usia Pertanggungjawaban Pidana Anak Sesuai Dengan Usia Dan Tingkat Kematangan} Anak.

Salah satu isu yang penting dalam wilayah kebijakan peradilan pidana adalah menyediakan mekanisme hukum yang merefleksikan transisi dari usia masa kanak-kanak yang dianggap tidak bersalah menuju kematangan dan sepenuhnya dapat bertanggung jawab menurut hukum pidana. Usia pertanggungjawaban tindak pidana merujuk pada usia seseorang dianggap memiliki kemampuan untuk menilai (kapasitas untuk membedakan benar atau salah) dan dapat memikul tanggung jawab atas tindak pidana yang dilakukannya. Dalam kaitan ini, terdapat 2 (dua) isu yakni: (i) usia di mana seorang anak dianggap memiliki kapasitas mental untuk melakukan tindak pidana; dan (ii) usia di mana anak dianggap layak untuk memikul tanggung jawab terhadap penuntutan dan sanksi formal atas tindak pidana yang dilakukannya. Seiring dengan isu ini terdapat 2 (dua) ketentuan mengenai tanggung jawab pidana yakni: (i) usia minimum pertanggungjawaban pidana; dan (ii) pembebanan secara gradual 
(bertingkat) tanggung jawab pidana yang mana bergantung pada pemahaman anak terhadap tindakan salah yang dilakukannya.

Selanjutnya, terdapat 3 (tiga) jenis perbedaan dari mens rea yakni:

a. maksud (intention); seseorang bermaksud melakukan actus reus;

b. sengaja tidak mau tahu (willful blindness): seseorang mengetahui kemungkinan tindakannya ilegal namum memilih untuk tidak menanyakan atau menyelidiki situasi tersebut;

c. tindak pidana karena kelalaian (criminal negligence); manakala seseorang tidak menyadari konsekuensi tindakannya.

Ketiga perbedaan tersebut, dapat digunakan untuk mengeksaminasi sampai sejauh mana kapasitas anak memahami tindak pidana yang dilakukannya. Dengan kata lain, anak dalam batas usia tertentu belum memiliki kemampuan untuk menganalisis risiko terhadap tindak pidana yang dilakukannya. Pada titik ini, usia dan tingkat kematangan anak menjadi tolak ukur untuk menentukan dan mengukur derajat mens rea anak-anak.

\section{Kebijakan Melalui Konsep Keadilan Restoratif}

Menurut Howard Zehr, keadilan restoratif dimaknai sebagai proses untuk melibatkan, memungkinkan keterlibatan pihak-pihak yang lebih luas, yakni para pihak yang mempunyai kepentingan atas suatu pelanggaran yang spesifik. Kemudian secara bersama, mengidentifikasi dan mengarahkan kerugian, kebutuhan, dan kewajiban dalam rangka menyembuhkan dan menempatkan hak para pihak sebagai titik yang mungkin dituju untuk diselesaikan. Kemudian menurut Sharpe keadilan restoratif memiliki karakteristik yang fundamental dengan beragam nilai yang disebut dengan pengikutsertaan (partisipasi), demokrasi, tanggung jawab, pemulihan, keamanan, penyembuhan, dan reintegrasi.

Selanjutnya menurut United Nations Office on Drugs and Crime (UNODC), keadilan restoratif merujuk pada proses untuk memecahkan tindak pidana (kejahatan) dengan memusatkan pada perbaikan kerugian (luka) korban, menetapkan pelaku bertanggung jawab atas tindakannya, dan melibatkan masyarakat dalam menyelesaikan konflik yang terjadi tersebut. Dengan demikian proses restoratif merupakan setiap proses yang mana korban dan pelaku atau individu lainnya atau anggota komunitas yang terpengaruh oleh suatu tindak pidana, mengambil bagian bersama secara aktif dalam penyelesaian berbagai masalah yang muncul akibat tindakan pidana tersebut dengan bantuan fasilitator.

\section{Kebijakan Melalui Konsep Diversi Dalam Peradilan Anak}

Diversi dapat dimaknai sebagai upaya menjauhkan suatu kasus dengan kriteria tertentu dari proses peradilan pidana formal menuju ke arah dukungan komunitas untuk menghindari dampak negatif yang diakibatkan oleh proses peradilan pidana. Pada dasarnya tindakan diversi dapat dilakukan pada tahapan manapun dalam proses peradilan pidana. Penerapan diversi bergantung pada keputusan polisi, jaksa, pengadilan, atau badan-badan sejenis. Namun demikian, dalam banyak sistem keputusan diversi dibuat pada awal proses peradilan pidana. Dengan demikian diversi merupakan kanalisasi kasus tertentu untuk dijauhkan dari sistem peradilan pidana yang pada umumnya berdasarkan kondisikondisi tertentu yang menempatkan pelaku pada posisi yang sulit (fait accompli).

Lebih jauh, menurut Van Rooyen, diversi dapat juga didefinisikan sebagai prima facie pengalihan suatu kasus dari upaya penyelesaian melalui proses persidangan yang normal. Hal ini berimplikasi bahwa tuntutan kepada pelaku berdasarkan kondisionalitas tertentu dapat ditarik mundur atau dihentikan. Selanjutnya pelaku harus berpartisipasi pada program khusus atau memulihkan korban. Diversi dapat juga disebut penyelesaian di luar pengadilan (out-of-court settlement) di mana tuntutan terhadap terdakwa dihentikan atau dicabut, namun sebagai gantinya tersangka harus mentaati persyaratan-persyaratan yang disepakati oleh para pihak. 


\section{Kebijakan Anak Yang Berhadapan Dengan Hukum Berdasarkan Hukum Internasional}

Diawali dengan Standar Aturan Minimum PBB mengenai Perlakuan terhadap Tahanan pada 1955, PBB kemudian mengadopsi sejumlah standar dan norma yang dirancang untuk memajukan administrasi peradilan di seluruh penjuru dunia. Standar dan norma tersebut diadopsi dalam wilayah kerja sama internasional, perlakuan terhadap pelaku tindak pidana, peradilan, penegakan hukum, peradilan pidana anak, perlindungan saksi, hukuman mati, pencegahan hukuman kejam dan tidak manusiawi, dan hak asasi manusia.

Penerapan standar dan norma PBB dapat dijadikan sebagai perangkat yang berguna untuk meningkatkan penghormatan dan pemajuan hak asasi manusia, peningkatan performa capaian sistem peradilan pidana, dan perlindungan terhadap masyarakat. Tidak hanya itu, instrumen tersebut dapat dijadikan sebagai landasan untuk mengembangkan parameter yang terukur terkait dengan kejujuran (fair play) dan efektivitas operasionalisasi sistem peradilan pidana nasional dari perspektif internasional.

\section{KESIMPULAN}

Kebijakan formulasi penanggulangan anak sebagai korban tindak pidana dalam sistem peradilan pidana di Indonesia harus di dilakukan dengan menggunakan pendekatan restorative juctice, yaitu proses penyelesaian yang dilakukan di luar sistem peradilan pidana (criminal justice system) dengan melibatkan korban, pelaku, keluarga korban dan pelaku, masyarakat serta pihak-pihak yang berkepentingan dengan suatu tindak pidana yang terjadi untuk mencapai kesepakatan dan penyelesaian. Kebijakan ini berangkat dari asumsi bahwa tanggapan atau reaksi terhadap pelaku delinkuensi anak tidak akan efektif tanpa adanya kerjasama dan keterlibatan dari korban, pelaku dan masyarakat.

Perlindungan hukum terhadap anak sebagai korban di dalam sistem peradilan pidana yang bersifat restorative justice dalam menangani persoalan-persoalan perkara anak yang berkonflik dengan hukum, maka perlu memperhatikan beberapa hal sebagai berikut: (a). Harmonisasi instrumen hukum nasional yang mengacu kepada standar instrumen internasional tentang perlindungan anak. Harmonisasi hukum ini dilakukan karena begitu banyaknya peraturan perundang-undangan di Indonesia yang mengatur tentang anak, disamping itu Indonesia merupakan bagian dari masyarakat internasional yang terikat dengan sejumlah konvensi maupun instrument hukum internasional lainnya yang bertujuan untuk memberikan perlindungan anak dalam rangka meningkatkan derajat, martabat dan kesejahteraan anak. (b) Batas Usia penahanan anak dan pertanggungjawaban pidana anak yang dapat diajukan ke sidang anak. Perbedaan batas usia minimal dan maksimal pertanggungjawaban pidana tidak hanya berdampak terhadap perbedaan penanganan dari sistem peradilan pidana anak, tetapi juga berhubungan dengan organisasi-organisasi dan institusi-institusi seperti pekerja sosial dan pelayanan anak. (c) Konsep diversi, yaitu mekanisme yang dimaksudkan untuk mengkongkritkan pendekatan keadilan yang restoratif. Di Pengadilan Negeri, hakim anak wajib melakukan diversi sebelum melakukan pemeriksaan terhadap perkara tindak pidana anak, karena diversi adalah perintah dari UU-SPPA. Dalam proses diversi, hakim anak diberi kesempatan selama 7 (tujuh) hari, wajib melibatkan pihak-pihak terkait dalam suatu musyawarah sesuai syarat dan ketentuan UU-SPPA di pengadilan negeri secara tertutup untuk umum di ruang khusus, dengan memperhatikan asas-asas penyelesaian perkara pidana anak.

\section{Daftar Pustaka}

Anna Volz, Advocacy Strategies Training Manual: General Comment No.10: Children's Rights in Juvenile Justice, Defence for Children International, 2009 
Agung Wahyono dan Ny. Siti Rahayu,Tinjauan Tentang Peradilan Anak di Indonesia, Sinar Grafika, Jakarta, 1993.

Abu Huraerah, Kekerasan Terhadap Anak, Cet. Ke 3, Nuansa Cendekia, 2012.

Apong Herlina, dkk, Perlindungan Terhadap Anak Yang Berhadapan dengan Hukum Manual Pelatihan Untuk POLISI, Jakarta: Polri dan Unicef. 2004.

Adam Graycar, The Age of Criminal Responsibility, Australian Institute of Criminology, 2000.

Andre Ata Ujan, Filsafat Hukum: Membangun Hukum, Membela Keadilan, Penerbit Kanisius, Yogyakarta, 2009.

Absori, Perlindungan Hukum Hak-Hak Anak Dan Implementasinya Di Indonesia Pada Era Otonomi Daerah, Fakultas Hukum Universitas Muhammadiyah Surakarta, 2008.

Arif Gosita, Aspek Hukum Perlindungan Anak dan Konvensi Hak-Hak Anak, Era Hukum Jurnal Ilmiah Ilmu Hukum, 1999, hlm 266

Arif Gosita, Makalah Seminar Nasional Peradilan Anak, Fakultas Hukum UNPAD, Bandung, 5 Oktober 1998

Arif Gosita, Masalah Korban Kejahatan, PT.Bhuana Ilmu Populer Kelompok Gramedia, Jakarta, 2004.

Andi Hamzah, Hukum Acara pidana Indonesia, Sinar Grafika, Jakarta, 2000.

Andi Hamzah, KUHP dan KUHAP, Rinefia Cipta, Jakarta, 2004.

Apong Herlina, et.al, Perlindungan Terhadap Anak Yang Berhadapan Dengan Hukum,UNICEF, Jakarta, 2004

Ann Skelton \& Boyane Tshehla, Child Justice in South Africa, Institute for Security Studies, Monograph 150 September 2008.

Alicia Victor, Sub-Report on Delivery: Restorative Justice, The National Prosecuting Authority of South Africa, 2006

Anthon F. Susanto, Wajah Peradilan Kita, Refika Aditama, Bandung, 2004.

Andre Ata Ujan, Filsafat Hukum: Membangun Hukum, Membela Keadilan, Penerbit Kanisius, Yogyakarta, 2009

Barbara Henkes, The Role of Education in Juvenile Justice in Eastern Europe and The Farmer Soviet Union, Constitutional $\mathbb{E}$ Legal Policy Institute, Hungary, 2000.

Benyamin Asri, Hak-Hak Tersangka dan Terdakwa Dalam Penyidikan, Penuntutan dan Peradilan, Tarsito, Bandung, 1989.

Barda Nawawi Arif, Bunga Rampai Kebijakan Hukum Pidana, Perkembangan Penyusunan Konsep KUHP Baru, Prenada Media Group, 2008.

Barda Nawawi Arief, Masalah Kebijakan Hukum dan Kebijakan Hukum Pidana dalam Penanggulangan Kejahatan, Prenada Media Group, Jakarta, 2007.

D.Y. Atta, Pokok-Pokok Pelaksanaan Sidang Perkara Anak di Pengadilan Negeri dalam Daerah Hukum Pengadilan Tinggi Jakarta, Bina Cipta, Jakarta, 1979.

Emelia Krisnawati, Aspek Hukum Perlindungan Anak, Cv. Utomo, Bandung, 2005.

Ediwarman, Peradilan Anak di Persimpangan Jalan dalam Prespektif Victimology (belajar dari kasus Raju), Vol.18 No. 1, April 2006, Jurnal Mahkamah : Pekan baru

G.S. Diponolo, Ilmu Negara, jilid 2, Balai Pustaka, Jakarta, 1975.

Gerry Maher, Age and Criminal Responsibility, Ohio State Journal of Criminal Law, Vol 2: 493.

Hangama Anwari, Justice for The Children: The situation for children in conflict with the law in Afghanistan,

UNICEF and AIHRC, tanpa tahun

Irma Setyowati Soemitro, Aspek Hukum Perlindungan Anak, Bumi aksara, Jakarta, 1990.

Irwanto, Perlindungan Anak, Prinsip dan Persoalan Mendasar, Makalah Seminar Kondisi dan Kondisi Penanganan anak Jermal, Medan, 1 September 1997, 
Jay S. Albanese, United Nations standards and norms, and their impact on criminal justice policy and practice dalam The Application of The United Nation Standard and Norms in Crime Prevention dan Criminal Justuce, United Nations Office on Drugs and Crime, 2003

Jean Tomkin, Orphans of Justice In search of the best interests of the child when a parent is imprisoned: A Legal Analysis, Quaker United Nations Office, 2009.

Jimmly Asshiddiqie, Penegakan Hukum, www.solusihukum.com, pada tanggal 15 September 2015

Jujun S. Suriasumantri, dalam Soetandyo Wignjosoebroto, Hukum, Paradigma, Metode dan Dinamika Masalahnya,Jakarta : Elsam dan Huma, 2002.

Johny Ibrahim, Teori dan Metodologi Penelitian Hukum Normatif, Malang : Bayumedia Publishing, 2006.

Kartini Kartono, Patologi Sosial Kenakalan Remaja, Rajawali, Jakarta, 1992.

Kartini Kartono, Patologi Sosial 2, Kenakalan Remaja, Rajawali Press, Jakarta.1993

Leden Marpaung, Unsur-unsur Perbuatan Yang Dapat Dihukum, Sinar Grafika, Jakarta, 1991.

Lilik Muladi, Kapita Selekta Hukum Pidana Kriminologi dan Viktimologi, PT. Djambatan, Jakarta, 2004/2007.

Lilik Mulyadi, Wajah Sistem Peradilan Pidana Anak Indonesia, Alumni, Bandung, 2014.

Muji Estiningsih, Fungsi Pengawasan DPRD, Penerbit Universitas Atma Jaya, Yogyakarta, 2005.

Moh. Kusnardi dan Harmaily Ibrahim, Pengantar Hukum Tata Negara Indonesia, Pusat Studi Hukum Tata Negara Fakultas Hukum UI, Jakarta, 1988.

Muladi, Kapita Selekta Sistem Peradilan Pidana, Semarang: Badan Penerbit Universitas Diponegoro. 2002.

Muhammad Joni, Aspek Hukum Perlindungan Anak Dalam Perspektif Konvensi Hak Anak, Citra Aditya Bakti, Bandung, 1999.

Maulana Hasan Wadong, Pengantar Advokasi dan hukum Perlindungan Anak, Grasindo, Jakarta, 2000.

Maidin Gultom, Perlindungan Hukum Anak Dalam Pemeriksaan Perkara Pidana Anak Di Indonesia, Usulan Penulisan Disertasi Program Dokter Ilmu Hukum UNPAR, 2002.

Muhammad Joni dan Zulchaina Z.Tanamas, Aspek Hukum Perlindungan Anak Dalam Perspektif Konvensi Hak Anak, Citra Aditya Bakti, Bandung, 1999.

Marjono Reksodipoetro, melihat kepada kejahatan dan penegakan hukum dalam batas-batas toleransi, pidato pengukuhan penerimaan jabatan guru besar tetap dalam ilmu hukum pada fakultas hukum Universitas Indonesia), tahun 1993.

Mardjono Reksodipoetro, Sistem Peradilan Pidana di Indonesia, Peranan Penegak Hukum Melawan Kejahatan, dikutip dari Hak Asasi Manusia dalam Sistem Peradilan Pidana, tahun 1994.

Muladi, Sistem Peradilan Pidana Indonesia, Citrabaru, Jakarta 1994.

Marlina, Peradilan Pidana Anak di Indonesia, Refika Aditama, Bandung, 2012.

Marlina, Buku Pengantar Konsep Diversi dan Restroactive Justice Dalam Hukum Pidana, Medan :USU Press, 2010.

Maidin Gultom, Perlindungan Hukum Terhadap Anak dalm Sistem Peradilan Pidana Anak di Indonesia, Refika Aditama,Bandung, 2008

Made Sadhi Astuti, Pemidanaan Terhadap Anak Sebagai Pelaku Tindak Pidana, (Malang Penerbit IKIP Malang, 1997).

Nashriana, Perlindungan Hukum Pidana Bagi Anak di Indonesia, PT. Raja Grafindo Persada, Jakarta, 2011 Otje Salman dan Anthon F. Susanto, Teori Hukum, Refika Aditama, Bandung, 2009.

Ontario Justice Education Network,Mens Rea / Actus Reus Handout, tanpa tahun

Paulus Hadisuprapto, Juvenile Delinquency Pemahaman dan Penanggulangannya, Bandung: PT. Citra Aditya Bakti. 1997.

Paulus Hadisuprapto, Delinkuensi Anak, Pemahaman dan Penanggulangannya.Malang :Bayumedia Publishing, 2008.

Peter Mahmud Marzuki, Penelitian Hukum, Kencana, Jakarta, 2008. 
Purnianti, Mamik Sri Supatmi, dan Ni Made Martini Tinduk, mengutip Harry E. Allen and Cliffford E. Simmonsen, dalam Correction in America: An Introduction, Analisa Situasi Sistem Peradilan Pidana Anak ( Juvenile Justice System ) di Indonesia, UNICEF, Indonesia, 2003.

Philipus M. Hadjon, Pengkajian Penelitian Hukum Normatif. Majalah Yuridika, Surabaya, Universitas Airlangga.

Petrus Irwan dan Pondapotan Simongkir, Lembaga Pemasyarakatan Dalam Perspektif Peradilan Pidana, Sinar Harapan, Jakarta. Tanpa tahun

Ramdlon Naning, Cita dan Citra Hak-hak Asasi Manusia di Indonesia, Lembaga Kriminologi Universitas Indonesia - Program Penunjang Bantuan Hukum Indonesia, Jakarta, 1983.

Rena Yulia, Viktimologi: Perlindungan Hukum Terhadap Korban Kejahatan, Graha Ilmu Yogyakarta, 2014.

Romli Atmasasmita, Teori dan Kapita Selekta Kriminologi, P.T Eresco, Bandung, 1992.

Romli Atmasasmita, Sistem Peradilan Pidana, Perspekrif Eksistensialisme dan Abolisionisme, Binacipta, Bandung, 1996.

Romli Atmasasmita, Problem Kenakalan Anak-Anak/ Remaja, Armico, Bandung, 1983.

Romli Atmasasmita, Bunga Rampai Kriminologi, Rajawali, Jakarta. 1984.

Satjipto Rahardjo, Ilmu Hukum, Citra Aditya, Bandung, 1996.

Satjipto Rahardjo, Masalah Penegakan Hukum Suatu Tinjauan Sosiologis, Sinar Baru, Bandung, 1989.

Soerjono Soekanto, Efektifitas Hukum dan Peranan Sanksi, Remedja Karya, Bandung, 1988

Sudarto, Hukum Pidana I, Yayasan Sudarto, Semarang, 1990.

Sudarsono, Kenakalan Remaja, Rineka Cipta, Jakarta, 1991.

Tali Gal, Victim to Partners: Child Victims and Restorative Justice, Thesis Submitted for the degree of PhD at the Australian National University, 2006

Utrecht, Hukum Pidana I, Universitas, Bandung, 1968.

Wagiati Soetedjo, Hukum Pidana Anak, PT Refika Aditama, Bandung, 2006.

Kitab Undang-undang Hukum Acara Pidana, Bumi Aksara, Jakarta, Tahun 1999.

Kitab Undang-Undang Hukum Pidana, Bumi Aksara, Jakarta Tahun 1999.

Undang-Undang Republik Indonesia Nomor 11 Tahun 2012 Tentang Sistem Peradilan Pidana Anak

Konvensi Hak Anak (KHA), 1989 (UN Convention on the Rights of the Child/CRC) 